\title{
The effect of a permafrost disturbance on growing-season carbon-dioxide fluxes in a high Arctic tundra ecosystem
}

\author{
Alison E. Cassidy, Andreas Christen, and Gregory H. R. Henry \\ Department of Geography, The University of British Columbia, 1984 West Mall, Vancouver, British Columbia, \\ V6T1Z2, Canada \\ Correspondence to: A. E. Cassidy (alison.cassidy@geog.ubc.ca)
}

Received: 9 October 2015 - Published in Biogeosciences Discuss.: 11 December 2015

Revised: 31 March 2016 - Accepted: 12 April 2016 - Published: 20 April 2016

\begin{abstract}
Soil carbon stored in high-latitude permafrost landscapes is threatened by warming and could contribute significant amounts of carbon to the atmosphere and hydrosphere as permafrost thaws. Thermokarst and permafrost disturbances, especially active layer detachments and retrogressive thaw slumps, are present across the Fosheim Peninsula, Ellesmere Island, Canada. To determine the effects of retrogressive thaw slumps on net ecosystem exchange (NEE) of $\mathrm{CO}_{2}$ in high Arctic tundra, we used two eddy covariance (EC) tower systems to simultaneously and continuously measure $\mathrm{CO}_{2}$ fluxes from a disturbed site and the surrounding undisturbed tundra. During the 32-day measurement period in the 2014 growing season, the undisturbed tundra was a small net sink (NEE $\left.=-0.1 \mathrm{~g} \mathrm{C} \mathrm{m}^{-2} \mathrm{~d}^{-1}\right)$; however, the disturbed terrain of the retrogressive thaw slump was a net source (NEE $=+0.4 \mathrm{~g} \mathrm{C} \mathrm{m}^{-2} \mathrm{~d}^{-1}$ ). Over the measurement period, the undisturbed tundra sequestered $3.8 \mathrm{~g} \mathrm{C} \mathrm{m}^{-2}$, while the disturbed tundra released $12.5 \mathrm{~g} \mathrm{C} \mathrm{m}^{-2}$. Before full leaf-out in early July, the undisturbed tundra was a small source of $\mathrm{CO}_{2}$ but shifted to a sink for the remainder of the sampling season (July), whereas the disturbed tundra remained a source of $\mathrm{CO}_{2}$ throughout the season. A static chamber system was also used to measure daytime fluxes in the footprints of the two towers, in both disturbed and undisturbed tundra, and fluxes were partitioned into ecosystem respiration $\left(R_{\mathrm{e}}\right)$ and gross primary production (GPP). Average GPP and $R_{\mathrm{e}}$ found in disturbed tundra were smaller $\left(+0.40 \mu \mathrm{mol} \mathrm{m}^{-2} \mathrm{~s}^{-1}\right.$ and $+0.55 \mu \mathrm{mol} \mathrm{m}^{-2} \mathrm{~s}^{-1}$, respectively) than those found in undisturbed tundra $\left(+1.19 \mu \mathrm{mol} \mathrm{m}^{-2} \mathrm{~s}^{-1}\right.$ and $+1.04 \mu \mathrm{mol} \mathrm{m}{ }^{-2} \mathrm{~s}^{-1}$, respectively). Our measurements indicated clearly that the permafrost disturbance changed the high Arctic tundra system
\end{abstract}

from a sink to a source for $\mathrm{CO}_{2}$ during the majority of the growing season (late June and July).

\section{Introduction}

Permafrost soils in the Arctic store vast amounts of carbon. The northern permafrost zone carbon inventory estimates the quantity of soil organic carbon stored in the top $3 \mathrm{~m}$ of frozen and unfrozen soils in northern circumpolar permafrost regions to be $1035 \pm 150 \mathrm{Pg}$, or approximately $50 \%$ of worldwide soil organic carbon (Tarnocai et al., 2009; Grosse et al., 2011; Hugelius et al., 2013; Schuur et al., 2015). Measurement difficulties and uncertainty regarding carbon storage in cryoturbated soils may result in an underestimation of current estimates by as much as a factor of 2 (Hugelius et al., 2013). As ground temperatures increase due to global climate change and permafrost thaws, this organic carbon becomes available for microbial decomposition (Schuur et al., 2008). McGuire et al. (2006) noted the implications for feedbacks to Arctic climate resulting from disturbance and enhanced decomposition including positive feedbacks as more $\mathrm{CO}_{2}$ released leads to warmer temperatures, thus exacerbating thaw and leading to further release of $\mathrm{CO}_{2}$. Conversely, a negative feedback may result if soil carbon inputs offset decomposition, as the balance between litter accumulation and decomposition determines the net effect on climate (Davidson and Janssens, 2006; Cornelissen et al., 2007).

Predicted climate change is expected to increase the frequency and extent of land surface disturbances in the Arctic (ACIA, 2005, Vincent et al., 2011). These disturbances are usually linked to thermokarst and affect soil temperature, wa- 
ter quality, and soil nutrients (Mackay, 1970; Lamoureux and Lafrenière, 2009; Lantz et al., 2009; Kokelj and Lewkowicz, 1998; Kokelj and Lewkowicz, 1999). In the high Arctic, these disturbances commonly take the form of retrogressive thaw slumps (RTS). RTS are initiated by the exposure of ground ice (sometimes linked to coastal erosion) and result in the removal of soil and vegetation as the slump retreats further upslope (Lantuit and Pollard, 2008). As ground ice thaws, the headwall regresses and will remain active until falling blocks of soil and vegetation insulate exposed ice and prevent further thaw (Burn and Friele, 1989). Within the overall landscape, these distinct landforms often create unique microclimates resulting in increased landscape heterogeneity (Ukraintseva, 2008; Lantz et al., 2009; Bosquet, 2011). Climate warming may cause differential responses in disturbed and undisturbed tundra. For example, the response of plants to increases in temperature may be intensified when disturbance occurs (Lantz et al., 2009). Lantz et al. (2009) suggested that disturbances play a more significant role in vegetation modification than temperature changes, particularly on the fine scale. We hypothesize that those changes in the landscape (slumping and vegetation loss) will have a significant effect on the carbon balance of tundra systems. However, no direct measurements of net ecosystem exchange (NEE) and its component fluxes, ecosystem respiration $\left(R_{\mathrm{e}}\right)$ and gross primary productivity (GPP), have been completed to determine the effect of these permafrost disturbances.

Eddy covariance (EC) has been used to quantify NEE in the Arctic, and measurements vary greatly, depending on location and ecosystem type. The magnitude of $\mathrm{CO}_{2}$ fluxes are generally greater at low latitudes than in the high Arctic (Lafleur et al., 2012) and in wet sedge areas than dry heath tundra (Kwon et al., 2006; Groendahl et al., 2007). Variability may be explained by plant composition and abundance, nutrient availability, substrate quantity, and soil organic matter (Mbufong et al., 2014). Typical mean daily values measured during the growing season ranged between 0.2 and $2.2 \mathrm{~g} \mathrm{C} \mathrm{m}^{-2} \mathrm{~d}^{-1}$ at a wide range of Arctic sites (Lafleur et al., 2012). Previous studies have found large interannual variability within and among sites, which can shift the site from a carbon sink to carbon source (Griffis and Rouse, 2001; Kwon et al., 2006; Merbold et al., 2009). Large variability in tundra vegetation communities over short distances increases the difficulty in assessing NEE fluxes across the Arctic and determining their responses to disturbance and environmental change (Lafleur et al., 2012).

Static chamber systems, which partition NEE into component fluxes GPP and $R_{\mathrm{e}}$, are an alternative method of measuring ecosystem fluxes. Chamber studies in the Arctic have found a loss of carbon during the winter and increasing sink potential with a longer growing season (Welker et al., 2000, 2004). At Alexandra Fiord, Ellesmere Island, experimental warming impacted NEE differently based on soil moisture, with a greater increase in respiration at dry than at wet sites (Welker et al., 2004). Across a latitudinal gradient, warm- ing tended to increase respiration, with the greatest increases found in dry ecosystems (Oberbauer et al., 2007).

While NEE values are generally similar between chamber and EC methods, differences are attributed to the scale of the measurements (Stoy et al., 2013). Fox et al. (2008) showed that there was large bias in upscaling chamber measurements, relative to EC values in a tundra ecosystem, due to microscale surface heterogeneity of the landscape. Further, in the high Arctic with $24 \mathrm{~h}$ of daylight, during which the sun remains relatively high above the horizon, the usual partitioning methods for EC measurements into component fluxes (Reichstein et al., 2012) are not applicable, as they rely on nighttime measurements or measurement during low light conditions. Consequently, to measure the impact of the RTS on the $\mathrm{CO}_{2}$ exchange of high Arctic tundra we used both EC and chamber measurements.

In this study, we analyse the impacts of RTS on $\mathrm{CO}_{2}$ exchange in a high Arctic tundra ecosystem. Our main research objective was to examine how growing season NEE and its component fluxes vary between an active RTS and undisturbed tundra.

\section{Study area}

Our research was conducted on the Fosheim Peninsula, located on western Ellesmere Island, Canada $\left(79^{\circ} 58^{\prime} 56^{\prime \prime} \mathrm{N}\right.$ $84^{\circ} 23^{\prime} 55^{\prime \prime} \mathrm{W}$ (WGS-84); elevation $100 \mathrm{~m}$ a.s.l.). The field site had an active, isolated retrogressive thaw slump (RTS) $\left(6300 \mathrm{~m}^{2}\right)$ within a relatively flat area and wind patterns were constrained (NNE-SSW) by its location near a shallow valley bottom (Figs. 1 and 2). Ice-rich permafrost is found throughout the study region and increased summer temperatures and precipitation over the past 20 years have resulted in greater occurrence of active layer detachment slides and RTS (Lewkowicz and Harris, 2005a). The geological substrate is mainly sandstones of the Eureka Sound group (Bell, 1996) with marine deposits of silts and fluvial sandy soils varying in thickness above bedrock (Robinson and Pollard, 1998). The limit of ocean inundation at the end of the last glaciation in the area lies at approximately $140 \mathrm{~m}$ a.s.l. (Bell, 1996), with limited vegetation above this level; our study location was located below the marine limit. Vegetation at the site was a relatively uniform dwarf-shrub-graminoid community on moderately drained, slightly alkaline soils. Vegetation located in the undisturbed tundra was dominated by the dwarf shrubs Salix arctica, Dryas integrifolia, the sedge Carex nardina, and mosses and lichens. Within the disturbance, the dominant plant species was the grass Puccinellia angustata, which is able to colonize the disturbed area and proliferate. Vegetation cover within the RTS varied based on moisture and proximity to undisturbed vegetation and was much lower than the surrounding undisturbed areas (with estimates of cover averaging $( \pm$ SE) $3( \pm 0.5) \%$ and $27( \pm 1.5) \%$ total cover, respectively). The nearest weather station, Eu- 


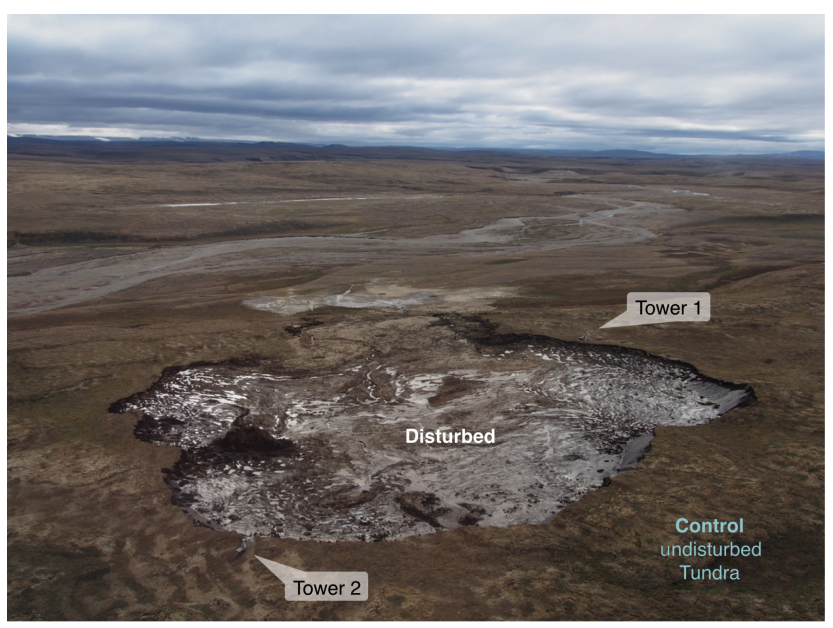

Figure 1. Aerial image of the dual eddy covariance system set-up with the location of both flux towers indicated. The valley trends NNE-SSW. View is to the south.

reka, is located $40 \mathrm{~km}$ to the west and has a mean temperature of $6.1^{\circ} \mathrm{C}$ and mean precipitation of $14.5 \mathrm{~mm}$ in July over the 1981-2010 period (Environment Canada, 2015).

\section{Materials and methods}

\subsection{Eddy covariance measurements of carbon-dioxide fluxes}

An appropriate sampling design was necessary to quantify the $\mathrm{CO}_{2}$ fluxes between land surface and atmosphere simultaneously from disturbed and undisturbed sites in close proximity (Hollinger and Richardson, 2005). We used a dual eddy covariance approach, which was advantageous over a single eddy covariance tower as we were able to measure fluxes simultaneously from disturbed tundra and the surrounding undisturbed tundra (Fig. 1; Fig. 2). However, direct placement of an EC system within the disturbance was not possible due to the active mass movements in the RTS creating a risk for researchers and equipment. Two towers were established on opposite sides of the RTS, at the boundary between disturbed and undisturbed terrain (Fig. 1). Tower 1 was established on the southern boundary of the RTS and Tower 2 was established on the northern boundary at a distance of $90 \mathrm{~m}$ from Tower 1 . Disturbed tundra were areas impacted by RTS, while undisturbed tundra were areas located outside the boundary of the RTS. This set-up allowed the measurement of fluxes containing signals from both areas simultaneously. By using turbulent source area modelling (see below), we then estimated the contribution of disturbed and undisturbed tundra to each of the signals.

Both EC systems were established on tripods located on the periphery of the active RTS on 26 June 2014 and operated continuously until 28 July 2014 . On each system the instru-
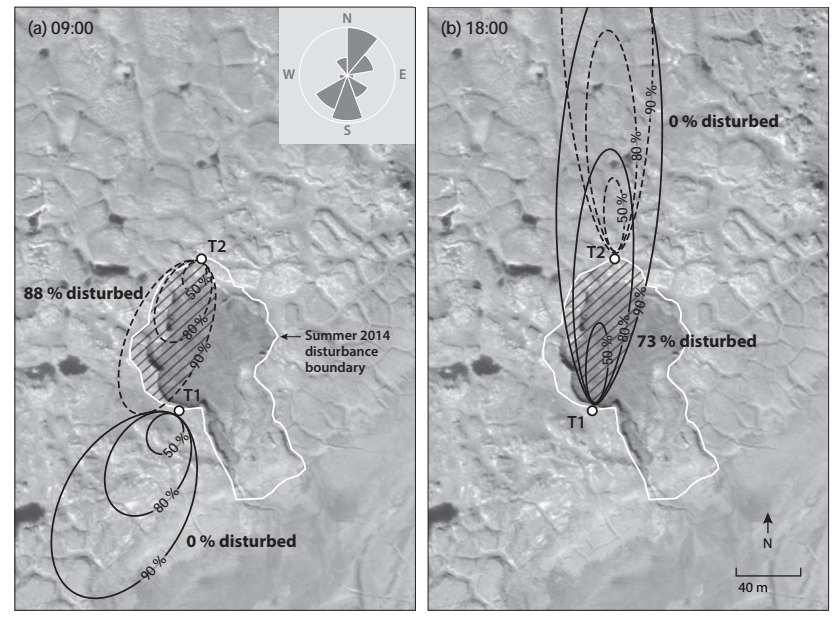

Figure 2. Turbulent source areas for two time steps on day of the year (DOY) 186 ((a) 09:00 and (b) 18:00), with ellipses displaying areas contributing to the given percentage of the signal from each instrument tower (T1 and T2). Three ellipses from each tower represent the 50, 80, and $90 \%$ cumulative source area. The shaded area represents a signal from the disturbed part of the surface. The white polygon represents the furthest extent of headwall retreat, as the initial image was taken in July 2013 (Worldview-2) and significant retreat occurred between image acquisition and the summer 2014 sampling period.

mentation included the following: an ultrasonic anemometer (CSAT-3, Campbell Scientific Inc., Logan, UT, USA) and a co-located infrared gas analyser (IRGA) (LI-7500, LI-COR Inc., Lincoln, NE, USA). The IRGA was tilted $30^{\circ}$ from the vertical to minimize issues associated with sensor heating and reduce the pooling of moisture on the windows (see Supplement). The IRGA and ultrasonic anemometer were established at a height of $1.3 \mathrm{~m}$ on both towers, a temperature and humidity sensor (HMP, Campbell Scientific Inc.) at $1 \mathrm{~m}$, a quantum sensor (SQ-110, Apogee Instruments Inc., Logan, UT, USA) at $1 \mathrm{~m}$, a net radiometer (NR Lite, Kipp \& Zonen B.V., Delft, the Netherlands) at $1 \mathrm{~m}$, and all sensors were attached to a data logger (CR1000, Campbell Scientific Inc.). This double EC sampling technique allowed for simultaneous sampling of fluxes from the disturbed tundra and the surrounding undisturbed (control) terrain for most time steps. Previous knowledge of wind direction $\vartheta$ based on the location of the disturbance within a valley constrained winds along the valley axis into up-valley wind $\left(0^{\circ}<\vartheta<40^{\circ}\right)$ and down-valley wind $\left(160^{\circ}<\vartheta<200^{\circ}\right)$ directions, which resulted in aligning the sector facing towards $290^{\circ}$, having a sector free of flow distortion from 140 to $80^{\circ}$ (distorted sector was 80 to $140^{\circ}$ ). The towers were established at a distance of $3 \mathrm{~m}$ from the slump edge to ensure stability and were moved periodically throughout the season due to the recession of the slump edge. Additionally, the potential impacts of step changes due to the placement of the flux tower at the boundary of disturbed and undisturbed tundra was mini- 
mized through the use of friction velocity thresholds and removing data with wind along the discontinuity with obvious flow distortion. Both IRGAs were calibrated prior to the field season using a two-point calibration in the lab against standards from the Greenhouse Gas Measurement Laboratory (GGML), Meteorological Service of Canada, using a zero gas and span gas of a known mixing ratio.

Fluxes of $\mathrm{CO}_{2}\left(F_{\mathrm{C}}\right)$ were computed in EddyPro ${ }^{\circledR}$ (V5.1.1, LI-COR Inc.) with a missing sample allowance of $30 \% . F_{\mathrm{C}}$ was calculated over a $30 \mathrm{~min}$ averaging interval using double rotation for tilt correction, block average detrending, contact time lag detection, and density corrections using mixing ratios (Burba et al., 2012). Data were quality checked using the flagging system proposed by Mauder and Foken (2004).

\subsection{Turbulent source area model}

To estimate the instantaneous turbulent source area that influences sampled NEE, a 2-D gradient diffusion and crosswind dispersion model (Kormann and Meixner, 2001) was run for all 30 min periods between 26 June 2014 and 28 July 2014 at a $1 \mathrm{~m}$ grid resolution over a domain of $300 \mathrm{~m} \times 300 \mathrm{~m}$ with the tower situated in the centre (see Fig. 2). Model inputs included wind direction $\vartheta\left({ }^{\circ}\right)$, standard deviation of the lateral wind component $\sigma_{\mathrm{v}}(\mathrm{m})$, roughness length $z_{0}(\mathrm{~m})$ and Obukhov length $L(\mathrm{~m})$ separately for each tower and for each time step. $\vartheta, \sigma_{\mathrm{v}}$, and $L$ were calculated directly by EddyPro ${ }^{\circledR}$ based on measurements by the two ultrasonic anemometers. Roughness length varied depending on whether the upwind surface in a particular time period was in the RTS or representing undisturbed tundra. $z_{0}$ was determined separately for $10^{\circ}$ wind direction bins based on the ensemble of measurements from the entire data set following Paul-Limoges et al. (2013). For each wind sector $\vartheta, z_{0}$ was calculated for cases with near-neutral stability $(-0.05<z / L<+0.05)$ using Eq. (1):

$z_{0}(\vartheta)=z \exp \left(-\frac{k \bar{u}}{u_{*}}\right)$

where $z$ is the measurement height $(1.3 \mathrm{~m}), k$ is the von Kármán constant (0.4), $\bar{u}$ is the measured mean horizontal wind $\left(\mathrm{m} \mathrm{s}^{-1}\right)$ from this wind direction, and $u_{*}$ is the simultaneously measured friction velocity $\left(\mathrm{m} \mathrm{s}^{-1}\right)$ calculated as $u_{*}=\left(\overline{u^{\prime} w^{\prime}}+{\overline{v^{\prime} w^{\prime}}}^{2}\right)^{0.25}$, where $\overline{u^{\prime} w^{\prime}}$ and $\overline{v^{\prime} w^{\prime}}$ are covariances of longitudinal $(u)$, lateral $(v)$, and vertical $(w)$ wind components. Mean wind $\bar{u}$ and covariances were calculated by EddyPro ${ }^{\circledR}$ based on measurements from the ultrasonic anemometer. The disturbed sectors of both towers had an average $z_{0}=0.032 \mathrm{~m}$, whereas the undisturbed sectors had an average $z_{0}=0.017 \mathrm{~m}$. Gridded flux footprints (or vertical per unit point source) $\phi(x, y)$ were calculated with a $1 \mathrm{~m}$ resolution for each $30 \mathrm{~min}$ step following Christen et al. (2011). A fraction of the flux footprint was predicted to be outside the $300 \mathrm{~m}$ study area, which was assumed to represent an undis- turbed (control) surface (as no additional permafrost disturbances were located in proximity to the towers).

The $300 \mathrm{~m} \times 300 \mathrm{~m}$ model domain included the entire disturbance, and a spatial mask $I(x, y)$ of the domain was created with a value of 1 inside the disturbance boundary and 0 for undisturbed tundra. For each grid-cell, $I(x, y)$ was multiplied by $\phi(x, y)$ and then summed to determine the fraction of the footprint that originates from inside the RTS (Eq. 2):

$\Phi_{\mathrm{d}}=\sum_{x=1}^{300} \sum_{y=1}^{300} I(x, y) \phi(x, y)$.

$\Phi_{\mathrm{d}}$ is the fraction of the tower signal (from 0 to 1 ) influenced by the disturbed surface of the RTS. The fraction of the signal influenced by the undisturbed tundra $\Phi_{c}$ is then calculated as $\Phi_{\mathrm{c}}=1-\Phi_{\mathrm{d}}$. By solving a set of linear equations (Eqs. 3 and 4), we are able to partition the component fluxes of $\mathrm{CO}_{2}$ (Fig. 2) from the disturbed tundra $\left(\mathrm{NEE}_{\mathrm{d}}\right)$ and from the undisturbed tundra $\left(\mathrm{NEE}_{\mathrm{c}}\right)$ from both towers $(\mathrm{T} 1$ and $\mathrm{T} 2$ ):

$\operatorname{NEE}(\mathrm{T} 1)=\Phi_{\mathrm{d}}(\mathrm{T} 1) \mathrm{NEE}_{\mathrm{d}}+\Phi_{\mathrm{c}}(\mathrm{T} 1) \mathrm{NEE}_{\mathrm{c}}$,

$\operatorname{NEE}(\mathrm{T} 2)=\Phi_{\mathrm{d}}(\mathrm{T} 2) \mathrm{NEE}_{\mathrm{d}}+\Phi_{\mathrm{c}}(\mathrm{T} 2) \mathrm{NEE}_{\mathrm{c}}$.

Turbulent source areas calculated for each time step over the sampling period are shown in Fig. 2. These two example time steps from Fig. 2 can be solved as follows. In the first time step (09:00), $\Phi_{c}$ for $\mathrm{T} 1$ is 1 ; therefore, the NEE $(\mathrm{T} 1)=\mathrm{NEE}_{\mathrm{c}}=-0.17 \mu \mathrm{mol} \mathrm{m} \mathrm{m}^{-2} \mathrm{~s}^{-1}$. For T2, $88 \%\left(\Phi_{\mathrm{d}}\right)$ was disturbed, while the remaining $12 \%$ was allocated as undisturbed $\left(\Phi_{\mathrm{c}}\right)$, so $\mathrm{NEE}_{\mathrm{c}}$ and $\mathrm{NEE}_{\mathrm{d}}$ were solved with NEE (T2) $=1.20 \mu \mathrm{mol} \mathrm{m} \mathrm{m}^{-2} \mathrm{~s}^{-1}$ and resulted in $\mathrm{NEE}_{\mathrm{d}}=1.39 \mu \mathrm{mol} \mathrm{m} \mathrm{m}^{-2} \mathrm{~s}^{-1}$. Corresponding to the second time step from Fig. 2 (18:00), T1 is influenced by both undisturbed and disturbed NEE as $\Phi_{\mathrm{d}}(\mathrm{T} 1)=0.73$ and $\Phi_{\mathrm{c}}(\mathrm{T} 1)=$ 0.27 , and NEE (T1) is $0.38 \mu \mathrm{mol} \mathrm{m}^{-2} \mathrm{~s}^{-1}$. At $\mathrm{T} 2, \Phi_{\mathrm{d}}$ is 0 , while $\Phi_{\mathrm{c}}$ is 1 , so NEE (T2) $=\mathrm{NEE}_{\mathrm{c}}=-0.03 \mu \mathrm{mol} \mathrm{m} \mathrm{m}^{-2} \mathrm{~s}^{-1}$. Consequently, $\mathrm{NEE}_{\mathrm{c}}=-0.03 \mu \mathrm{mol} \mathrm{m} \mathrm{m}^{-2} \mathrm{~s}^{-1}$ and $\mathrm{NEE}_{\mathrm{d}}=$ $0.54 \mu \mathrm{mol} \mathrm{m}^{-2} \mathrm{~s}^{-1}$.

Calculations of $\mathrm{NEE}_{\mathrm{d}}$ and $\mathrm{NEE}_{\mathrm{c}}$ were numerically unstable under multiple combinations of surface fractions, including when winds were parallel to the edge of the disturbance and when $\Phi_{\mathrm{d}}$ and $\Phi_{\mathrm{c}}$ were roughly equal to one another. As a result, values where the absolute difference between $\Phi_{\mathrm{d}}$ and $\Phi_{c}$ was less than 0.05 were removed and fluxes were gapfilled as detailed below during these periods.

The resulting $\mathrm{NEE}_{\mathrm{c}}$ and $\mathrm{NEE}_{\mathrm{d}}$ were compared and fluxes that had a difference from the daily average that was greater than 5 standard deviations of the $30 \mathrm{~min}$ values of the same day (applied iteratively) were removed. For further analysis, half-hour fluxes were averaged to calculate hourly fluxes. If one of the two 30 min values was invalidated, then the hourly value was calculated based on the remaining other $30 \mathrm{~min}$ period. Hourly gaps that still existed were then filled using the following methods: (a) gaps in $\mathrm{NEE}_{\mathrm{c}}$ and $\mathrm{NEE}_{\mathrm{d}}$ of less 
than $2 \mathrm{~h}$ were filled using a linear interpolation; and (b) gaps greater than $2 \mathrm{~h}$ were filled using aggregate averaging over a rolling 3-day window selecting the same time of the day. The cleaned and filled data set is composed of $86 \%$ original data and $14 \%$ gap filled (of a total of 750 data points; 106 of these were modelled). Data were also removed during times of maintenance, when the towers were moved, and when manual chamber or vegetation measurements were made within the tower footprint.

\subsection{Portable chamber system}

On 27 June 2014, 63 opaque PVC collars (10 cm diameter; $A=78.5 \mathrm{~cm}^{2} ; 6 \mathrm{~cm}$ depth) were installed across the source areas of $\mathrm{T} 1$ and $\mathrm{T} 2$, in both the disturbed and undisturbed zones (disturbed tundra $N=21$; undisturbed tundra $N=42$ ). They were inserted $4 \mathrm{~cm}$ into the ground so as to minimally disturb soil and vegetation and were left to protrude $2 \mathrm{~cm}$ above the soil surface. As moss cover was minimal and discontinuous, the location of the ground surface could be easily identified as the upper surface of the soil. Collar locations were randomly determined based on the generation of random distances and angles from the flux tower within disturbed and undisturbed flux source areas, with a minimum distance of $2 \mathrm{~m}$ and a maximum distance of $30 \mathrm{~m}$ from the towers. The disturbed areas of the RTS were not entirely devoid of vegetation, as clumps of soil and plants existed sporadically throughout the disturbance; 9 of 21 collars contained at least one individual plant. Measurements of $\mathrm{CO}_{2}$ fluxes began on 29 June to allow the immediate disturbance effects of installation to dissipate.

A non-steady-state vented portable chamber system similar to Jassal et al. (2005) was used to measure fluxes from each collar using transparent and opaque chambers. The measurement head was a PVC chamber with a volume of $1.4 \times 10^{-3} \mathrm{~m}^{3}$ (height: $15.6 \mathrm{~cm}$; diameter: $10.7 \mathrm{~cm}$ ). Fluxes from all collars were measured six times throughout the study period at 5-day intervals. The chamber head was placed on each collar and a foam gasket sealed the connection between the collar and the chamber head. Measurements were made for $2 \mathrm{~min}$. A pump (flow rate $600 \mathrm{~cm}^{3} \mathrm{~min}^{-1}$ ) circulated air from the chamber head into a portable, batteryoperated IRGA (LI-840, LI-COR Inc., Lincoln, USA) and back into the chamber head through a closed circuit. The IRGA determined $\mathrm{CO}_{2}$ mixing ratios $\left(\left[\mathrm{CO}_{2}\right]\right.$ in ppm) and water vapour concentrations at a temporal resolution of $1 \mathrm{~Hz}$ during the run. The IRGA was calibrated in the laboratory prior to sampling using a two-point calibration, against standards from the Greenhouse Gas Measurement Laboratory (GGML), Meteorological Service of Canada, using a zero gas and span gas of a known mixing ratio. The IRGA has been calibrated in the laboratory for effective volume, which exceeds geometric volume by $10 \%$ due to the absorption of $\mathrm{CO}_{2}$ on the walls of the chamber and the contribution of nearsurface soil porosity (Jassal et al., 2012). This calibration was carried out in the laboratory by determining the difference between two flux measurements, one immediately following the other, where the second measurement included a known rate of injection of $\mathrm{CO}_{2}$ into the chamber.

Fluxes were calculated from $\Delta\left[\mathrm{CO}_{2}\right] / \Delta t$ (linear regression over $2 \mathrm{~min}$, discarding the first $10 \mathrm{~s}$ ), using Eq. (5):

$F_{\mathrm{c}}=\frac{\rho \bar{D} \mathrm{~V}}{A} \frac{\Delta\left[\mathrm{CO}_{2}\right]}{\Delta t}$,

where $\rho$ is molar air density $\left(\mathrm{mol} \mathrm{m}^{-3}\right)$ calculated from measured air temperature, $D$ is dilution considering $\left[\mathrm{H}_{2} \mathrm{O}\right]$, $\Delta\left[\mathrm{CO}_{2}\right] / \Delta t$ is the rate of change in $\mathrm{CO}_{2}$ mixing ratio over time $\left(\mu \mathrm{mol} \mathrm{mol}{ }^{-1} \mathrm{~s}^{-1}\right)$, and $V$ and $A$ are chamber volume and area, respectively. To obtain measurements of NEE, the transparent chamber head was used on each collar. For ecosystem respiration $\left(R_{\mathrm{e}}\right)$ measurements, the chamber was removed and allowed to equilibrate to ambient $\left[\mathrm{CO}_{2}\right]$ before being replaced on the collar, and a dark shroud was placed over the transparent chamber head to block out all photosynthetically active radiation (PAR). GPP was calculated based on GPP $=R_{\mathrm{e}}-\mathrm{NEE}$, where NEE is negative if GPP $>R_{\mathrm{e}}$ and both $R_{\mathrm{e}}$ and GPP are positive values. NEE and $R_{\mathrm{e}}$ measurements were taken within minutes at each collar allowing for comparison. Measurements were conducted over a $7 \mathrm{~h}$ sampling period and were always completed between 10:00 and 18:00 CDT to reduce diurnal changes in light and temperature. Chamber measurements were only made during daytime periods; thus, respiration includes heterotrophic respiration from soil carbon losses and residual photosynthetic respiration. The site has $24 \mathrm{~h}$ of light, and photosynthesis (and associated respiration) can occur over the entire $24 \mathrm{~h}$ period.

\subsection{Environmental variable sampling}

Soil temperature loggers (HOBO Pendant Temperature/Light Data Loggers, Onset Computer Corporation, Bourne, MA, USA) were installed at randomly selected collars throughout the study area within $0.5 \mathrm{~m}$ of the collar. A total of 21 HOBO sensors (14 sensors located in undisturbed tundra and 7 sensors in disturbed tundra) measured soil temperatures at $5 \mathrm{~cm}$ every minute throughout the sampling season. The soil temperatures were aggregated into hourly averages to allow for comparison with hourly EC data. Soil moisture was measured adjacent to collars every 5 days as volumetric water content $(\%)$ using a time-domain reflectometry (TDR) sensor (HydroSenseII Soil Water TDR, Campbell Scientific Inc., Logan, UT, USA) with $12 \mathrm{~cm}$ rods. After rain events, measurements were delayed for $24 \mathrm{~h}$. 


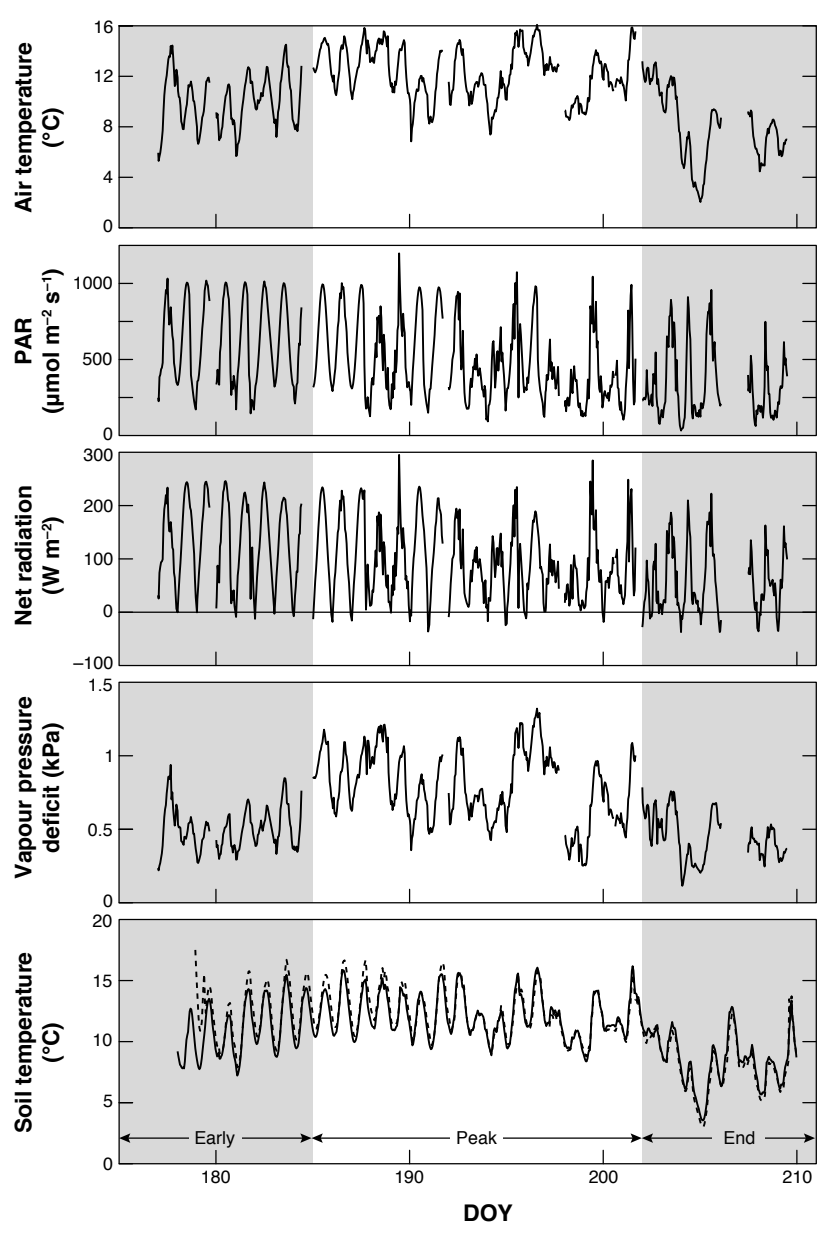

Figure 3. Meteorological conditions during the 2014 growing season at T2. Height of all instrumentation on the tower was $1 \mathrm{~m}$ above the canopy. Soil temperatures were measured at a depth of $-5 \mathrm{~cm}$, and mean temperature is shown for the disturbance (dashed line; $n=7$ ) and undisturbed tundra (solid line; $n=14$ ). DOY: day of the year.

\section{Results}

\subsection{Environmental conditions during the study period}

The measured variations over the study period in air temperature $\left(T_{\mathrm{a}}\right)$, net radiation ( $Q *$, over undisturbed tundra), incoming PAR, and vapour pressure deficit (VPD) measured at Tower 2 and soil temperature from the disturbance and undisturbed tundra area near Tower 2 are shown in Fig. 3. The early season was characterized by clear skies; however, the middle of July was dominated by a period of cloudy, cooler conditions (exemplified by decreased $Q *$, Fig. 3). Air and soil temperatures showed distinct diurnal and seasonal patterns (Fig. 3; Fig. 4), characterized by an increase in both temperatures early in the season, which was sustained through the peak season, followed by decreases in both during the end of the season. Three distinct periods (early, peak,

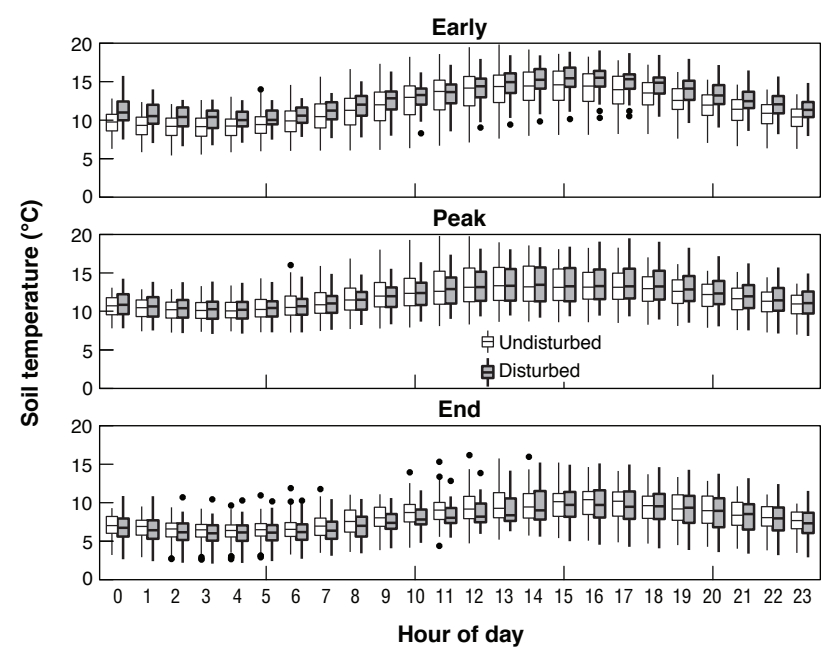

Figure 4. Ensemble average diurnal course of soil temperatures in the disturbed and undisturbed sites throughout the season. Early season: 24 June-4 July; peak season: 5-21 July; end of season: 2229 July. Boxes show the 25 th and 75 th percentiles; dots are the outliers; horizontal lines are medians.

and late season) were identified throughout the study period based on plant phenological development and environmental conditions (Fig. 3; Fig. 4). These periods varied in their duration (see Table 1). During the measurement period, $T_{\mathrm{a}}$ increased from $10.5^{\circ} \mathrm{C}$ in the early season (DOY: $175-185$ ) to $12.2^{\circ} \mathrm{C}$ during the peak of the growing season (DOY: 186 202) and then decreased to $7.2^{\circ} \mathrm{C}$ by the end of July. On a diurnal basis, disturbed soils reached greater temperatures than undisturbed soils earlier in the season $\left(12.6\right.$ and $11.6^{\circ} \mathrm{C}$, respectively) but cooled off more quickly later in the season (7.8 and $8.1{ }^{\circ} \mathrm{C}$, respectively), due to the lack of insulating vegetation (Mann Whitney $U$ Test $(V=181992, p<0.01))$. In undisturbed terrain, soil moisture decreased during peak season, while soil moisture increased steadily in disturbed tundra (Table 1). Overall, soil moisture values were significantly greater (Mann Whitney $U$ Test $(V=7023, p<0.01))$ in disturbed soils $(24.1 \% \pm 0.9)$ than in undisturbed soils $(13.9 \% \pm 0.4)$.

\subsection{NEE of disturbed and undisturbed tundra}

The early season was characterized by leaf emergence, cool temperatures, and elevated soil moisture (Table 1) due to recent snowmelt. The peak season was characterized by maximum leaf area and flowering of vegetation and a decrease in surface soil moisture as warm air temperatures and large VPD persisted. The late season was characterized by the beginning of leaf senescence, dry soils, and the greatest active layer depth. Precipitation was minimal throughout the season (1.2 $\mathrm{mm}$ at Eureka), with isolated rain events occurring on 17, 21, and 26 July. There was a significant windstorm 
Table 1. Summary of net ecosystem exchange (NEE), soil temperatures (Soil $T$ ) and soil moisture (Soil $M$ ) from disturbed (subscript d) and undisturbed (subscript c) tundra, and air temperature (measured at T2) throughout the growing season.

\begin{tabular}{|c|c|c|c|}
\hline Variable & Early season & Peak season & End season \\
\hline DOY & $175-185$ & 186-202 & $203-210$ \\
\hline Date & 24 June-4 July & 5-21 July & 22-29 July \\
\hline $\begin{array}{l}\mathrm{NEE}_{\mathrm{c}} \\
\left(\mu \mathrm{mol} \mathrm{m}{ }^{-2} \mathrm{~s}^{-1}\right)^{1}\end{array}$ & $0.080 \pm 0.03$ & $-0.28 \pm 0.03$ & $-0.015 \pm 0.05$ \\
\hline $\begin{array}{l}\mathrm{NEE}_{\mathrm{d}} \\
\left(\mu \mathrm{mol} \mathrm{m}{ }^{-2} \mathrm{~s}^{-1}\right)^{2}\end{array}$ & $0.55 \pm 0.03$ & $0.25 \pm 0.03$ & $0.58 \pm 0.13$ \\
\hline $\begin{array}{l}\text { Air temperature }\left({ }^{\circ} \mathrm{C}\right) \\
\text { Mean }( \pm \mathrm{SE}) \\
\operatorname{Min} / \max \end{array}$ & $\begin{array}{l}10.5 \pm 0.17 \\
5.3 / 15.0\end{array}$ & $\begin{array}{l}12.2 \pm 0.10 \\
6.9 / 16.1\end{array}$ & $\begin{array}{l}7.2 \pm 0.22 \\
2.0 / 12.0\end{array}$ \\
\hline $\begin{array}{l}\text { Soil } T_{\mathrm{c}}\left({ }^{\circ} \mathrm{C}\right)^{3} \text { at } 5 \mathrm{~cm} \\
\text { Mean }( \pm \mathrm{SE}) \\
\text { Min/max }\end{array}$ & $\begin{array}{l}11.6 \pm 0.05 \\
5.4 / 19.8\end{array}$ & $\begin{array}{l}11.9 \pm 0.29 \\
6.9 / 19.8\end{array}$ & $\begin{array}{l}8.1 \pm 0.05 \\
2.6 / 16.2\end{array}$ \\
\hline $\begin{array}{l}\text { Soil } T_{\mathrm{d}}\left({ }^{\circ} \mathrm{C}\right)^{4} \text { at } 5 \mathrm{~cm} \\
\text { Mean }( \pm \mathrm{SE}) \\
\operatorname{Min} / \max \end{array}$ & $\begin{array}{l}12.6 \pm 0.07 \\
6.6 / 19.1\end{array}$ & $\begin{array}{l}11.9 \pm 0.04 \\
6.8 / 19.5\end{array}$ & $\begin{array}{l}7.8 \pm 0.07 \\
2.1 / 15.2\end{array}$ \\
\hline $\begin{array}{l}\text { Soil } M_{\mathrm{c}}(\%)^{5} \\
\text { Mean }( \pm \mathrm{SE}) \\
\text { Min/max }\end{array}$ & $\begin{array}{l}14.4 \pm 0.5 \\
3.4 / 28.4\end{array}$ & $\begin{array}{l}12.9 \pm 0.4 \\
1.1 / 31.6\end{array}$ & $\begin{array}{l}16.9 \pm 1.0 \\
0.6 / 34.2\end{array}$ \\
\hline $\begin{array}{l}\text { Soil } M_{\mathrm{d}}(\%)^{6} \\
\text { mean }( \pm \mathrm{SE}) \\
\min / \max \end{array}$ & $\begin{array}{l}20.5 \pm 0.8 \\
9.7 / 41.2\end{array}$ & $\begin{array}{l}24.8 \pm 1.0 \\
4.1 / 45.4\end{array}$ & $\begin{array}{l}30.5 \pm 1.6 \\
6.9 / 44.8\end{array}$ \\
\hline $\begin{array}{l}{ }^{1} \mathrm{NEE}_{\mathrm{c}} \text { average net } \mathrm{CO}_{2} \text { flux } \mathrm{f} \\
{ }^{2} \mathrm{NEE}_{\mathrm{d}} \text { : average net } \mathrm{CO}_{2} \text { flux } \\
{ }^{3} \text { Soil } T_{\mathrm{c}} \text { : average soil temperat } \\
{ }^{4} \text { Soil } T_{\mathrm{d}} \text { : average soil tempera } \\
{ }^{5} \text { Soil } M_{\mathrm{c}} \text { : average soil tempera } \\
{ }^{6} \text { Soil } M_{\mathrm{d}} \text { : average soil tempera }\end{array}$ & $\begin{array}{l}\text { undisturbed (control) } \\
\text { disturbed tundra. } \\
\text { from undisturbed tund } \\
\text { from disturbed tundra } \\
\text { from undisturbed tun } \\
\text { from disturbed tundr }\end{array}$ & & \\
\hline
\end{tabular}

beginning on 22 July and that lasted $24 \mathrm{~h}$, with wind speeds (as determined from the raw $20 \mathrm{~Hz}$ spikes) of up to $21 \mathrm{~m} \mathrm{~s}^{-1}$.

$\mathrm{NEE}_{\mathrm{c}}$ and $\mathrm{NEE}_{\mathrm{d}}$ were analysed separately for three periods (early, peak, and late season). In the undisturbed tundra, $\mathrm{NEE}_{\mathrm{c}}$ was initially a small $\mathrm{CO}_{2}$ source in the early period and transitioned to a small sink as photosynthesis increased during the peak season. In the late season, $\mathrm{NEE}_{\mathrm{c}}$ became a small source consistent with decreased air and soil temperatures and the beginning of leaf senescence. This was in contrast with fluxes measured in the disturbed area $\left(\mathrm{NEE}_{\mathrm{d}}\right)$, which remained a $\mathrm{CO}_{2}$ source throughout the sampling period and displayed only slightly dampened values during peak season. Overall, $\mathrm{NEE}_{\mathrm{c}}$ and $\mathrm{NEE}_{\mathrm{d}}$ were significantly different throughout the sampling period (MannWhitney $U$ Test $(V=45839, p<0.01)$ ).

Aggregate fluxes calculated over the study period showed an overall loss of $\mathrm{CO}_{2}$ from disturbed tundra and a modest $\mathrm{CO}_{2}$ sink in the undisturbed tundra (Fig. 6). Daily averages of $\mathrm{NEE}_{\mathrm{c}}$ ranged from -0.89 to $+0.54 \mathrm{~g} \mathrm{C} \mathrm{m}^{-2} \mathrm{day}^{-1}$.
$\mathrm{NEE}_{\mathrm{d}}$ ranged from -0.29 to $+1.63 \mathrm{~g} \mathrm{C} \mathrm{m}^{-2} \mathrm{day}^{-1}$. During the early season, the average daily $\mathrm{NEE}_{\mathrm{c}}$ was a small source of $\mathrm{CO}_{2}$ to the atmosphere $\left(+0.07 \mathrm{~g} \mathrm{C} \mathrm{m}^{-2}\right.$ day $\left.^{-1}\right)$, while disturbed tundra was a greater source of $\mathrm{CO}_{2}\left(\mathrm{NEE}_{\mathrm{d}}=\right.$ $+0.55 \mathrm{~g} \mathrm{C} \mathrm{m}^{-2}$ day $\left.^{-1}\right)$. During peak growth, this shifted as the undisturbed tundra sequestered $-0.29 \mathrm{~g} \mathrm{C} \mathrm{m}^{-2}$ day $^{-1}$ and disturbed tundra continued to emit $\mathrm{CO}_{2}$ at an average of $+0.26 \mathrm{~g} \mathrm{C} \mathrm{m}^{-2} \mathrm{day}^{-1}$. During the end of the sampling season, the undisturbed tundra was a very small sink of $\mathrm{CO}_{2}$ with mean NEE of $-0.02 \mathrm{~g} \mathrm{C} \mathrm{m}^{-2} \mathrm{day}^{-1}$ and the NEE of the disturbed tundra was $+0.47 \mathrm{~g} \mathrm{C} \mathrm{m}^{-2} \mathrm{day}^{-1}$. Over the duration of the entire sampling period, the disturbed tundra was a source of $\mathrm{CO}_{2}$, with an average of $+0.39 \mathrm{~g} \mathrm{C} \mathrm{m}^{-2}$ day ${ }^{-1}$, while the undisturbed tundra was a sink for $\mathrm{CO}_{2}$ with an average uptake of $-0.12 \mathrm{~g} \mathrm{C} \mathrm{m}^{-2}$ day $^{-1}$ (Fig. 5). In total, the undisturbed tundra sequestered $3.8 \mathrm{~g} \mathrm{C} \mathrm{m}^{-2}$, while the disturbed tundra released $12.5 \mathrm{~g} \mathrm{C} \mathrm{m}^{-2}$ over the 32-day measurement period. 




Figure 5. Ensemble diurnal course of $\mathrm{CO}_{2}$ fluxes from the retrogressive thaw slump (disturbed) and undisturbed tundra separated into the three sampling periods: top (early season), middle (peak season), and bottom (end season). Boxes show the 25th and 75th percentiles; black circles are outliers; horizontal lines are medians.

Diurnal NEE from the tower systems corresponds with soil temperatures. In disturbed areas, as soil temperatures warmed, $\mathrm{CO}_{2}$ emissions increased, consistent with increased respiration. However, fluxes in undisturbed areas showed increased sequestration during midday, due to greater photosynthetic activity dominating over respiration increases.

Temporal patterns of fluxes and climatic and environmental variables were analysed for disturbed and undisturbed areas. In the disturbed area, regression analysis revealed strong relationships between NEE and soil temperature, PAR, $T_{\mathrm{a}}$, and VPD for the early and peak season periods $(p<0.001)$, while PAR was the most important control during the late season $\left(r^{2}=0.50, p<0.001\right)$. Over the undisturbed tundra, correlations between NEE and environmental variables varied throughout the sampling period. During the early season, PAR was most strongly correlated $\left(r^{2}=0.16, p<0.001\right)$ with NEE; however, during the peak season temperature $\left(r^{2}=0.08, p<0.001\right)$ and vapour pressure deficit (VPD) $\left(r^{2}=0.08, p<0.001\right)$ became important controls on NEE. At the end of the sampling season once again PAR was most strongly correlated with $\operatorname{NEE}\left(r^{2}=0.25, p<0.001\right)$ in the undisturbed tundra.

\subsection{Partitioning of NEE}

Measurements from the static chamber system were allocated to one of the three seasonal periods, allowing comparison with EC data (Fig. 7). The NEE values measured us-

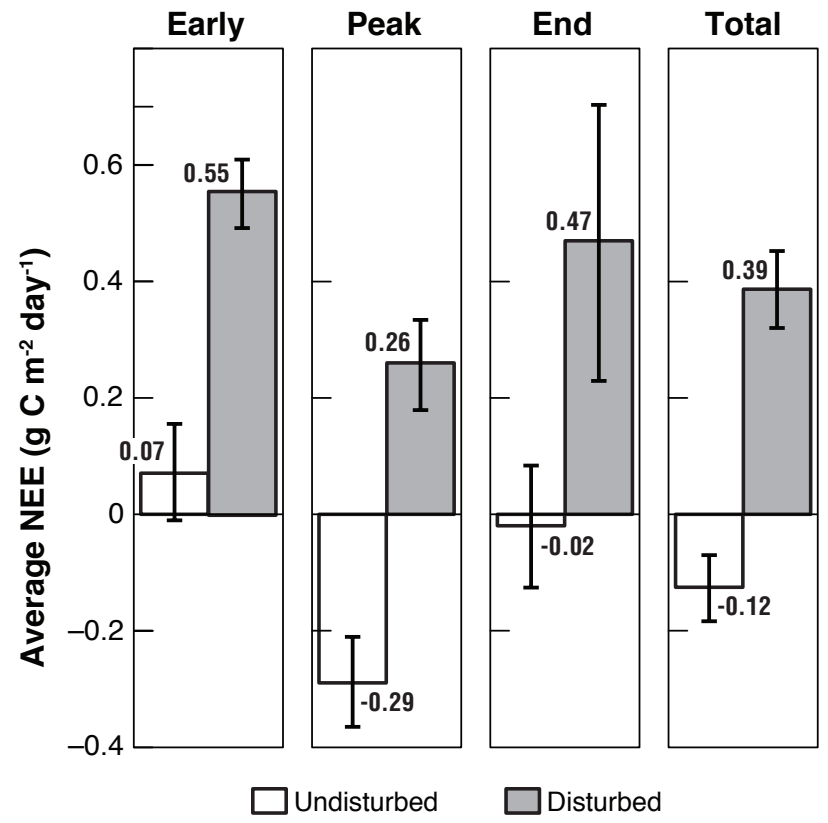

Figure 6. Average daily net $\mathrm{CO}_{2}$ flux for the three sampling periods as measured by the two EC systems and the net effect for the entire season.

ing the chamber technique supported the EC measurements but allowed fluxes to be partitioned into their component parts. The chamber measurements showed that the magnitude of GPP and $R_{\mathrm{e}}$ were roughly similar, resulting in minimal NEE in both disturbed and undisturbed areas (Table 2; Fig. 8). Variability in GPP was greater in the undisturbed tundra with values up to $8.03 \mu \mathrm{mol} \mathrm{m}{ }^{-2} \mathrm{~s}^{-1}$, while the maximum GPP in the disturbed tundra reached $2.47 \mu \mathrm{mol} \mathrm{m}^{-2} \mathrm{~s}^{-1} . R_{\mathrm{e}}$ ranged up to $+5.92 \mu \mathrm{mol} \mathrm{m}^{-2} \mathrm{~s}^{-1}$ in the undisturbed tundra and up to $+2.23 \mu \mathrm{mol} \mathrm{m}^{-2} \mathrm{~s}^{-1}$ in the disturbed tundra. Over the sampling season in the disturbed areas, chambermeasured GPP averaged $0.40 \mu \mathrm{mol} \mathrm{m}^{-2} \mathrm{~s}^{-1}$, increasing during peak season to $0.45 \mu \mathrm{mol} \mathrm{m}^{-2} \mathrm{~s}^{-1}$ before falling to $0.24 \mu \mathrm{mol} \mathrm{m}^{-2} \mathrm{~s}^{-1}$ in the late season. Respiration was greatest during the early season with $+0.70 \mu \mathrm{mol} \mathrm{m}^{-2} \mathrm{~s}^{-1}$, decreasing to $+0.53 \mu \mathrm{mol} \mathrm{m}^{-2} \mathrm{~s}^{-1}$ during peak season and finally to $+0.35 \mu \mathrm{mol} \mathrm{m}{ }^{-2} \mathrm{~s}^{-1}$ during the late season. These opposing fluxes resulted in the disturbed tundra being a small source for $\mathrm{CO}_{2}$ throughout the entire sampling season. NEE measured by the chamber system varied between +0.05 and $+0.41 \mu \mathrm{mol} \mathrm{m}^{-2} \mathrm{~s}^{-1}$ in the disturbance with the largest NEE occurring early in the season due to high respiration. $R_{\mathrm{e}}$ was always greater in magnitude than GPP over disturbed tundra, resulting in positive NEE values.

The undisturbed areas were small sources of $\mathrm{CO}_{2}$ early in the season as $R_{\mathrm{e}}$ outpaced productivity. During the early season GPP averaged $0.85 \mu \mathrm{mol} \mathrm{m} \mathrm{m}^{-2} \mathrm{~s}^{-1}$, nearly doubling during peak season to $1.47 \mu \mathrm{mol} \mathrm{m} \mathrm{m}^{-2} \mathrm{~s}^{-1}$ before falling to $1.00 \mu \mathrm{mol} \mathrm{m}^{-2} \mathrm{~s}^{-1}$ late in the season. $R_{\mathrm{e}}$ in the undisturbed 
Table 2. Summary of measurements (mean \pm SE) from the portable chamber system $\left(\right.$ in $\left.\mu \mathrm{mol} \mathrm{m}^{-2} \mathrm{~s}^{-1}\right)$.

\begin{tabular}{llrrrr}
\hline Variable & Location & Early & Peak & End & Total \\
\hline DOY & & $175-185$ & $186-202$ & $203-210$ & \\
\hline \multirow{2}{*}{ NEE } & undisturbed & $0.25 \pm 0.10$ & $-0.33 \pm 0.15$ & $-0.37 \pm 0.15$ & $-0.14 \pm 0.13$ \\
& disturbed & $0.31 \pm 0.12$ & $0.07 \pm 0.13$ & $0.11 \pm 0.07$ & $0.15 \pm 0.06$ \\
\hline GPP & undisturbed & $0.85 \pm 0.16$ & $1.47 \pm 0.26$ & $1.00 \pm 0.19$ & $1.19 \pm 0.19$ \\
& disturbed & $0.39 \pm 0.14$ & $0.45 \pm 0.16$ & $0.24 \pm 0.08$ & $0.40 \pm 0.03$ \\
\hline \multirow{2}{*}{$R_{\mathrm{e}}$} & undisturbed & $1.10 \pm 0.13$ & $1.14 \pm 0.15$ & $0.62 \pm 0.06$ & $1.04 \pm 0.12$ \\
& disturbed & $0.70 \pm 0.08$ & $0.53 \pm 0.10$ & $0.35 \pm 0.05$ & $0.55 \pm 0.06$ \\
\hline
\end{tabular}

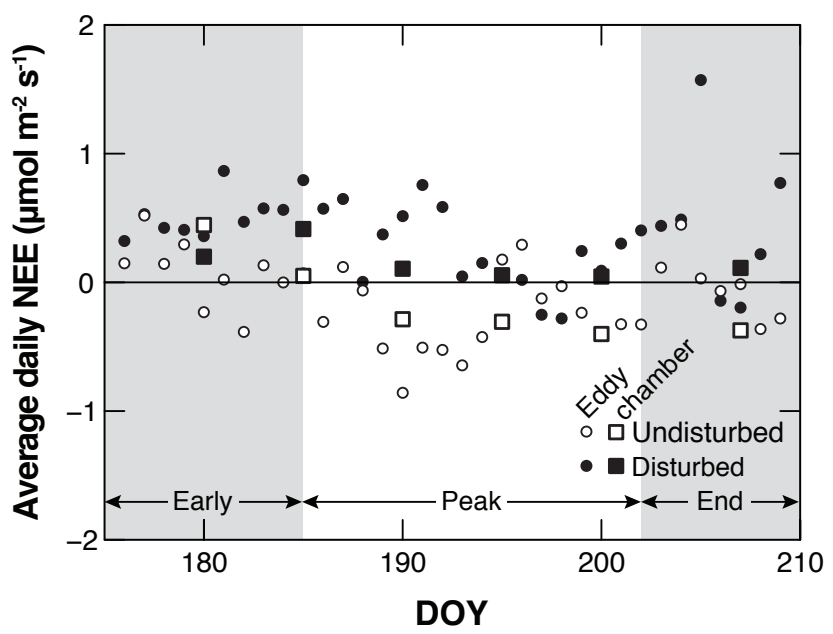

Figure 7. Comparison of NEE measurements from static chamber (square) and calculated from the two EC systems (circle). Open symbols represent measurements from undisturbed tundra, while closed symbols are measurements in the disturbed areas. Measurements were made in 21 collars in each of the disturbed and both undisturbed footprint areas of the EC towers.

tundra ranged from +0.62 to $+1.14 \mu \mathrm{mol} \mathrm{m}^{-2} \mathrm{~s}^{-1}$, with the greatest respiration occurring during peak growth. Both GPP and $R_{\mathrm{e}}$ peaked during the middle of the sampling period (mid July), before decreasing at the end of the season, but GPP was always greater in magnitude than $R_{\mathrm{e}}$.

\section{Discussion}

Over the majority of the 2014 growing season (late June and July), the RTS at our high Arctic site was a $\mathrm{CO}_{2}$ source, while undisturbed tundra was a small sink. All fluxes were quite low but similar to those measured in other high Arctic sites (Lafleur et al., 2012). Multi-year measurements of NEE in high Arctic tundra indicate that the initial uptake of carbon coincides with snowmelt and increases in $\mathrm{CO}_{2}$ emission rates correspond with deep and long-lasting snowpack (Lund et al., 2012). Arctic sites show significant interannual variabil-

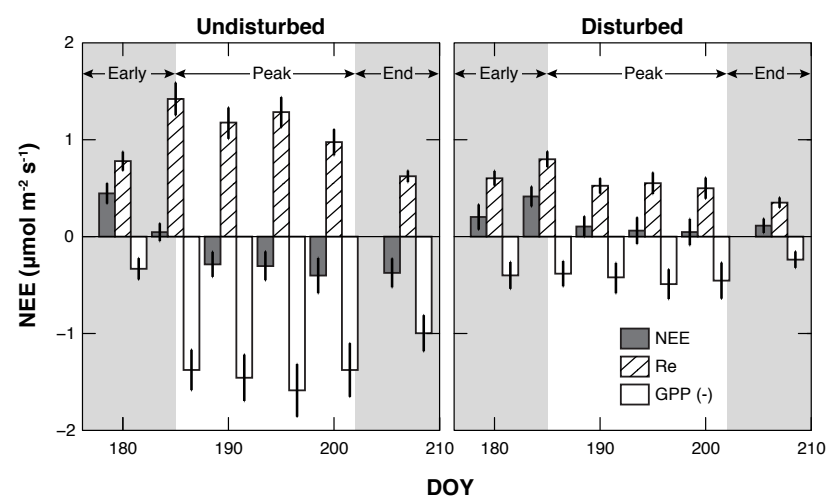

Figure 8. Partitioning of NEE data from static chamber measurements into component fluxes, GPP and $R_{\mathrm{e}}$, for the undisturbed and disturbed sites. Measurements were made in 21 collars during daytime hours in each of the disturbed and both undisturbed footprint areas of the EC towers.

ity, which is controlled by temperature; increased temperatures may result in enhanced emissions (Griffis and Rouse, 2001; Kwon et al., 2006; Merbold et al., 2009; Lund et al., 2012). In the high Arctic, soil moisture differences result in variations in ecosystem respiration (measured using chamber systems) and may enhance the impacts of warming (Welker et al., 2004). Warming has been found to increase respiration along a latitudinal gradient with the greatest increases found in dry ecosystems (Oberbauer et al., 2007).

Based on chamber measurements, we found that permafrost disturbance alters carbon dynamics by decreasing GPP and $R_{\mathrm{e}}$ (Fig. 7). However, reductions in GPP are greater than reductions in $R_{\mathrm{e}}$, resulting in the disturbance becoming a net carbon source. Decreases in GPP are due to lower vegetation cover within disturbed terrain. Decreases in respiration have been found within slumps and slides and are linked with carbon export from the disturbed area (Abbott and Jones, 2015; Beamish et al., 2014). Respiration measured in other high Arctic polar desert sites was positively correlated with soil moisture (Emmerton et al., 2015). This balance between reduced $R_{\mathrm{e}}$ as a result of disturbance and potential increases as a result of increased soil moisture may 
result in the greater magnitude of $R_{\mathrm{e}}$ relative to GPP and thus the overall shift to carbon source within the disturbance. Our chamber study only measured daytime fluxes; thus, reduced respiration may be due to decreases in plant respiration in addition to heterotrophic respiration processes.

Despite the small magnitude of these high Arctic fluxes, there was a considerable effect of the permafrost disturbance as the net $\mathrm{CO}_{2}$ emissions from the disturbance were approximately 3 times larger than the net sequestration in the undisturbed tundra. Overall, the double EC system approach coupled with a source area model proved to be an effective method of accurately partitioning measured fluxes into undisturbed and disturbed contributions, and values were consistent with the static chamber measurements.

By separating the growing season into three periods related to plant phenology, we were better able to identify differences in NEE between undisturbed and disturbed tundra throughout the sampling period in June and July 2014. Initial sampling corresponded with leaf emergence, and as the season progressed, plant growth and leaf area increased, resulting in increased photosynthetic activity. The changes in NEE also corresponded to differences in PAR during the three periods of the growing season. These phenological changes, especially in leaf emergence, growth, and senescence, can be compared to the shift in $\mathrm{CO}_{2}$ fluxes as initially the undisturbed tundra was a source of $\mathrm{CO}_{2}$, but during peak growth there was a distinct shift to $\mathrm{CO}_{2}$ sink. By the end of the sampling season, vegetation has begun to senesce, and this was reflected in reduced sink strength of $\mathrm{NEE}_{\mathrm{c}}$ in the undisturbed tundra. The disturbed areas contained low vegetation cover, resulting in a very low magnitude of GPP. Throughout the season, the environmental controls on $\mathrm{CO}_{2}$ fluxes in the disturbed tundra were PAR, $T_{\mathrm{a}}$, and VPD during the early and peak season, while PAR was a control in the late season.

Estimates of landscape-level impacts of permafrost disturbances in an $81 \mathrm{~km}^{2}$ ice-free land area on the Fosheim Peninsula, which included the area used for our study, were determined from satellite imagery and ground truthing in 2013. The analyses revealed that permafrost disturbances currently accounted for $0.34 \mathrm{~km}^{2}$ or only $0.4 \%$ of the landscape (A. C. A. Rudy, personal communication, 2015). Although the landscape area directly impacted by disturbance at this time is minimal, indirect impacts such as the lateral export of dissolved and particulate organic matter (hence, carbon) through streams and the hydrologic network are also important (Lamoureux and Lafrenière, 2009; Kokelj and Lewkowicz, 1998, 1999). The frequency and magnitude of these land surface disturbances appear to be increasing across the Fosheim Peninsula (and elsewhere in the Arctic) as a result of the warming climate, thus exacerbating these impacts (Lewkowicz, 1990; Lewkowicz and Harris, 2005b; Lantz and Kokelj, 2008). The increasing frequency and magnitude of these disturbances will affect the carbon balance on the landscape scale and could result in increased net $\mathrm{CO}_{2}$ emissions from these areas in the future. Organic carbon stored within permafrost has the potential to be released to the atmosphere as permafrost thaws (Schuur et al., 2008; Hicks Pries et al., 2011, 2013). We quantified this release to the atmosphere and demonstrated that these permafrost disturbances are sources of $\mathrm{CO}_{2}$ over the measurement period during the growing season and are likely sources throughout the year.

Potentially, some of the carbon in the soils could also be released in the form of methane (Anisimov, 2007; IPCC, 2007; Walter Anthony et al., 2012). Soil oxygen availability has been found to influence permafrost carbon that is released as both carbon dioxide and methane, and under aerobic conditions significantly more carbon is released as $\mathrm{CO}_{2}$ than $\mathrm{CH}_{4}$ (Lee et al., 2012). We expect that methane release was relatively minimal from both the undisturbed and disturbed sites because of the aerobic conditions present in the moderately drained soils found in our study location. However, we also expect increased release of carbon with the deepening of the active layer and the increase in frequency and magnitude of permafrost disturbances. In addition, inorganic carbon released with the dissolution of carbonates and weathering may result in the ventilation of $\mathrm{CO}_{2}$ and thus increased emissions (Lovett et al., 2006; Perez-Priego et al., 2013; Serrano-Ortiz et al., 2010). With increasing soil moisture, soil ventilation associated with carbonates may increase overall $R_{\mathrm{e}}$ (Emmerton et al., 2015). However, slow carbon evolution in tundra soils (as a result of the release of inorganic carbon from carbonates) would limit this influence (Billings et al., 1977).

Due to logistical constraints, our sampling period was limited to approximately 30 days after snowmelt had occurred. As these disturbances were dynamic in nature, the site could not be left alone as personnel were needed to monitor the slide edge location and adjust the equipment as needed. Leaving the site unmanned would have put the equipment at risk. Shoulder season and winter respiration have been shown to be significant in various studies for year-round estimates of the effects on the carbon cycle (Nordstroem et al., 2001; Welker et al., 2004; Johansson et al., 2006; Humphreys and Lafleur, 2011; Wang et al., 2011; Lund et al., 2012); however, only growing season fluxes were considered in our study. Starr and Oberbauer (2003) found photosynthetic activity in vascular plants under snow, further indicating the importance of fluxes outside the snow-free period. These fluxes were not considered in our study and could alter the annual carbon balance. However, year-round measurements of carbon exchange in areas impacted by permafrost thaw in Alaska indicate that these areas act as sources of carbon over multiple years (Vogel et al., 2009).

\section{Conclusions}

Using a dual EC sampling approach, in combination with the turbulent source area model and complemented by static chamber measurements, we were able to determine fluxes 
from one representative retrogressive thaw slump nearly continuously over the majority of the 2014 growing season. We found that these disturbances modify the NEE of the tundra, changing it from a net sink to a source of $\mathrm{CO}_{2}$. Based on daytime flux partitioning, the disturbance reduced the magnitude of both $R_{\mathrm{e}}$ and GPP, although reductions in GPP were greater. The dual EC approach in combination with the source area model allowed accurate assessments of the contributions of disturbed and undisturbed areas to $\mathrm{CO}_{2}$ fluxes, so we could quantify the effect of permafrost disturbance on NEE. This approach may be preferable to measurements taken using manual portable chamber systems due to the continuous sampling frequency and spatial integration of the signal.

\section{The Supplement related to this article is available online at doi:10.5194/bg-13-2291-2016-supplement.}

Acknowledgements. Funding for this study was provided by grants to G. H. R. Henry from the Natural Science and Engineering Research Council of Canada (NSERC) (NSERC Frontier Discovery Program - ADAPT) and ArcticNet and to A. E. Cassidy from the Northern Scientific Training Program, Polar Knowledge Canada. Selected instrumentation was funded by grants to A. Christen from NSERC and the Canadian Foundation for Innovation (CFI). We thank the Polar Continental Shelf Program for logistical support. Derek van der Kamp and Chris Greyson-Gaito assisted in the field and Rick Ketler assisted with equipment testing and calibration prior to fieldwork. Thank you to Vincent St. Louis (University of Alberta), Andrew Black (The University of British Columbia), Paul Jassal (The University of British Columbia), and Paul Treitz (Queen's University) for providing additional equipment, imagery, and scientific guidance.

Edited by: D. Obrist

\section{References}

Abbott, B. W. and Jones, J. B.: Permafrost collapse alters soil carbon stocks, respiration, $\mathrm{CH}_{4}$, and $\mathrm{N}_{2} \mathrm{O}$ in upland tundra, Glob. Change Biol., 21, 4570-4587, doi:10.1111/gcb.13069, 2015.

ACIA: Arctic Climate Impact Assessment and Arctic Monitoring and Assessment Programme and Program for the Conservation of Arctic Flora and Fauna and International Arctic Science Committee, Cambridge University Press, New York, USA, 2005.

Anisimov, O. A.: Potential feedback of thawing permafrost to the global climate system through methane emission, Environ. Res. Lett., 2, 045016, doi:10.1088/1748-9326/2/4/045016, 2007.

Beamish, A., Neil, A., Wagner, I., and Scott, N. A.: Short-term impacts of active layer detachments on carbon exchange in a High Arctic ecosystem, Cape Bounty, Nunavut, Canada, Pol. Biol., 37, 1459-1468, 2014.
Bell, T.: The last glaciation and sea level history of Fosheim Peninsula, Ellesmere Island, Canadian High Arctic, Can. J. Earth Sci., 33, 1075-1086, 1996.

Billings, W. D., Peterson, K. M., Shaver, G. R., and Trent, A. W.: Root growth, respiration, and carbon dioxide evolution in an arctic tundra soil, Arctic Alp. Res., 9, 129-137, 1977.

Bosquet, L.: The effects of observed and experimental climate change and permafrost disturbance on tundra vegetation in the western Canadian High Arctic, Canadian theses, Kingston, Ontario, 2011.

Burba, G., Schmidt, A., Scott, R. L., Nakai, T., Kathilankal, J., Fratini, G., Hanson, C., Law, B., McDermitt, D. K., Eckles, R., Furtaw, M., and Velgersdyk, M.: Calculating $\mathrm{CO}_{2}$ and $\mathrm{H} 2 \mathrm{O}$ eddy covariance fluxes from an enclosed gas analyzer using an instantaneous mixing ratio, Glob. Change Biol., 18, 385-399, doi:10.1111/j.1365-2486.2011.02536.x, 2012.

Burn, C. and Friele, P.: Geomorphology, Vegetation Succession, Soil Characteristics and Permafrost in Retrogressive Thaw Slumps near Mayo, Yukon Territory, Arctic, 42, 31-40, 1989.

Christen, A., Coops, N. C., Crawford, B. R., Kellett, R., Liss, K. N., Olchovski, I., Tooke, T. R., Van Der Laan, M., and Voogt, J. A.: Validation of modeled carbon-dioxide emissions from an urban neighborhood with direct eddycovariance measurements, Atmos. Environ., 45, 6057-6069, doi:10.1016/j.atmosenv.2011.07.040, 2011.

Cornelissen, J. H. C., Van Bodegom, P. M., Aerts, R., Callaghan, T. V., Van Logtestijn, R. S. P., Alatalo, J., Stuart Chapin, F., Gerdol, R., Gudmundsson, J., Gwynn-Jones, D., Hartley, A. E., Hik, D. S., Hofgaard, A., Jónsdóttir, I. S., Karlsson, S., Klein, J. A., Laundre, J., Magnusson, B., Michelsen, A., Molau, U., Onipchenko, V. G., Quested, H. M., Sandvik, S. M., Schmidt, I. K., Shaver, G. R., Solheim, B., Soudzilovskaia, N. A., Stenström, A., Tolvanen, A., Totland, Ø., Wada, N., Welker, J. M., Zhao, X., Brancaleoni, L., Brancaleoni, L., De Beus, M. A. H., Cooper, E. J., Dalen, L., Harte, J., Hobbie, S. E., Hoefsloot, G., Jägerbrand, A., Jonasson, S., Lee, J. A., Lindblad, K., Melillo, J. M., Neill, C., Press, M. C., Rozema, J., and Zielke, M.: Global negative vegetation feedback to climate warming responses of leaf litter decomposition rates in cold biomes, Ecol. Lett., 10, 619-627, doi:10.1111/j.1461-0248.2007.01051.x, 2007.

Davidson, E. A. and Janssens, I. A.: Temperature sensitivity of soil carbon decomposition and feedbacks to climate change, Nature, 440, 165-173, doi:10.1038/nature04514, 2006.

Emmerton, C. A., St. Louis, V. L., Humphreys, E. R., Gamon, J. A., Barker, J. D., and Pastorello, G. Z.: Net ecosystem exchange of $\mathrm{CO}_{2}$ with rapidly changing high Arctic landscapes, Glob. Change Biol., 22, 1185-1200, doi:10.1111/gcb.13064, 2015.

Environment Canada: Canadian Climate Normals 1981-2010 Station Data, Environment Canada, available at: http://www. climate.weather.gc.ca (last access: 15 April 2015), 2015.

Fox, A. M., Huntley, B., Lloyd, C. R., Williams, M., and Baxter, R.: Net ecosystem exchange over heterogeneous Arctic tundra: Scaling between chamber and eddy covariance measurements, Global Biogeochem. Cy., 22, GB2027, doi:10.1029/2007GB003027, 2008.

Griffis, T. J. and Rouse, W. R.: Modelling the interannual variability of net ecosystem $\mathrm{CO}_{2}$ exchange at a subarctic sedge fen, Glob. Chang. Biol., 7, 511-530, 2001. 
Groendahl, L., Friborg, T., and Soegaard, H.: Temperature and snow-melt controls on interannual variability in carbon exchange in the high Arctic, Theor. Appl. Climatol., 88, 111-125, doi:10.1007/s00704-005-0228-y, 2007.

Grosse, G., Harden, J., Turetsky, M., McGuire, A. D., Camill, P., Tarnocai, C., Frolking, S., Schuur, E. A. G., Jorgenson, T., Marchenko, S., Romanovsky, V., Wickland, K., French, N., Waldrop, M., Bourgeau-Chavez, L., and Striegl, R. G.: Vulnerability of high-latitude soil organic carbon in North America to disturbance, J. Geophys. Res., 116, G00K06, doi:10.1029/2010JG001507, 2011.

Hicks Pries, C. E., Schuur, E. A. G., and Crummer, K. G.: Holocene Carbon Stocks and Carbon Accumulation Rates Altered in Soils Undergoing Permafrost Thaw, Ecosystems, 15, 162-173, doi:10.1007/s10021-011-9500-4, 2011.

Hicks Pries, C. E., Schuur, E. G., and Crummer, K. G.: Thawing permafrost increases old soil and autotrophic respiration in tundra: partitioning ecosystem respiration using $\delta(13) \mathrm{C}$ and $\Delta(14) \mathrm{C}$., Glob. Change Biol., 19, 649-661, doi:10.1111/gcb.12058, 2013.

Hollinger, D. Y. and Richardson, A. D.: Uncertainty in eddy covariance measurements and its application to physiological models, Tree Physiol., 25, 873-885, doi:10.1093/treephys/25.7.873, 2005.

Hugelius, G., Tarnocai, C., Broll, G., Canadell, J. G., Kuhry, P., and Swanson, D. K.: The Northern Circumpolar Soil Carbon Database: spatially distributed datasets of soil coverage and soil carbon storage in the northern permafrost regions, Earth Syst. Sci. Data, 5, 3-13, doi:10.5194/essd-5-3-2013, 2013.

Humphreys, E. and Lafleur, P.: Does earlier snowmelt lead to greater $\mathrm{CO}_{2}$ sequestration in two low Arctic tundra ecosystems?, Geophys. Res. Lett., 38, L09703, doi:10.1029/2011GL047339, 2011.

IPCC: Climate Change 2007: The Physical Science Basis, Intergovernmental Panel on Climate Change, 446, 727-728, 2007.

Jassal, R., Black, A., Novak, M., Morgenstern, K., Nesic, Z., and Gaumont-Guay, D.: Relationship between soil $\mathrm{CO}_{2}$ concentrations and forest-floor $\mathrm{CO}_{2}$ effluxes, Agr. Forest Meteorol., 130, 176-192, doi:10.1016/j.agrformet.2005.03.005, 2005.

Jassal, R. S., Black, T. A., Nesic, Z., and Gaumont-Guay, D.: Using automated non-steady-state chamber systems for making continuous long-term measurements of soil $\mathrm{CO}_{2}$ efflux in forest ecosystems, Agr. Forest Meteorol., 161, 57-65, doi:10.1016/j.agrformet.2012.03.009, 2012.

Johansson, T., Malmer, N., Crill, P. M., Friborg, T., Åkerman, J. H., Mastepanov, M., and Christensen, T. R.: Decadal vegetation changes in a northern peatland, greenhouse gas fluxes and net radiative forcing, Glob. Change Biol., 12, 2352-2369, doi:10.1111/j.1365-2486.2006.01267.x, 2006.

Kokelj, S. and Lewkowicz, A.: Long-term influence of active-layer detachment sliding on permafrost slope hydrology, Hot Weather Creek, Ellesmere Island, Canada, Int. Conf. Permafrost, 55, 583589, 1998.

Kokelj, S. and Lewkowicz, A.: Salinization of permafrost terrain due to natural geomorphic disturbance, Fosheim Peninsula, Ellesmere Island, Arctic, 52, 372-385, 1999.

Kormann, R. and Meixner, F. X.: An analytical footprint model for non-neutral stratification, Boundary-Layer Meteorol., 99, 207224, doi:10.1023/A:1018991015119, 2001.

Kwon, H.-J., Oechel, W. C., Zulueta, R. C., and Hastings, S. J.: Effects of climate variability on carbon sequestration among adjacent wet sedge tundra and moist tussock tundra ecosystems, J. Geophys. Res.-Biogeosci., 111, G03014, doi:10.1029/2005JG000036, 2006.

Lafleur, P., Humphreys, E., St Louis, V., Myklebust, M., Papakyriakou, T., Poissant, L., Barker, J., Pilote, M., and Swystun, K.: Variation in peak growing season net ecosystem production across the Canadian Arctic, Environ. Sci. Tech., 46, 7971-7977, 2012.

Lamoureux, S. and Lafrenière, M.: Fluvial impact of extensive active layer detachments, Cape Bounty, Melville Island, Canada, Arctic, Antarct. Alp. Res., 41, 59-68, doi:10.1657/1523-043041.1.59, 2009.

Lantuit, H. and Pollard, W. H.: Fifty years of coastal erosion and retrogressive thaw slump activity on Herschel Island, southern Beaufort Sea, Yukon Territory, Canada, Geomorphology, 95, 84$102,2008$.

Lantz, T. C. and Kokelj, S. V.: Increasing rates of retrogressive thaw slump activity in the Mackenzie Delta region, N.W.T., Canada, Geophys. Res. Lett., 35, L06502, doi:10.1029/2007GL032433, 2008

Lantz, T. C., Kokelj, S. V., Gergel, S. E. and Henry, G. H. R.: Relative impacts of disturbance and temperature: persistent changes in microenvironment and vegetation in retrogressive thaw slumps, Glob. Change Biol., 15, 1664-1675, doi:10.1111/j.1365-2486.2009.01917.x, 2009.

Lee, H., Schuur, E. A. G., Inglett, K. S., Lavoie, M., and Chanton, J. P.: The rate of permafrost carbon release under aerobic and anaerobic conditions and its potential effects on climate, Glob. Change Biol., 18, 515-527, doi:10.1111/j.13652486.2011.02519.x, 2012.

Lewkowicz, A. G.: Morphology, frequency and magnitude of active-layer detachment slides, Fosheim Peninsula, Ellesmere Island, N.W.T., Nordicana, 54, 111-118, 1990.

Lewkowicz, A. and Harris, C.: Morphology and geotechnique of active-layer detachment failures in discontinuous and continuous permafrost, northern Canada, Geomorphology, 69, 275-297, doi:10.1002/ppp.522, 2005a.

Lewkowicz, A. G. and Harris, C.: Frequency and magnitude of active-layer detachment failures in discontinuous and continuous permafrost, northern Canada, Permafr. Periglac. Process., 16, 115-130, 2005b.

Lovett, G. M., Cole, J. J., and Pace, M. L.: Is net ecosystem production equal to ecosystem carbon accumulation?, Ecosystems, 9, 152-155, 2006

Lund, M., Falk, J. M., Friborg, T., Mbufong, H. N., Sigsgaard, C., Soegaard, H., and Tamstorf, M. P.: Trends in $\mathrm{CO}_{2}$ exchange in a high Arctic tundra heath, 2000-2010, J. Geophys. Res. Biogeosci., 117, G02001, doi:10.1029/2011JG001901, 2012.

Mackay, J.: Disturbances to the tundra and forest tundra environment of the western Arctic, Can. Geotech. J., 7, 420-432, 1970.

Mauder, M. and Foken, T.: Documentation and Instruction Manual of the Eddy Covariance Software Package TK2, Arbeitsergebn, Univ. Bayreuth, Abt. Mikrometeorol, Bayreuth, Germany, 2004.

Mbufong, H. N., Lund, M., Aurela, M., Christensen, T. R., Eugster, W., Friborg, T., Hansen, B. U., Humphreys, E. R., JackowiczKorczynski, M., Kutzbach, L., Lafleur, P. M., Oechel, W. C., Parmentier, F. J. W., Rasse, D. P., Rocha, A. V., Sachs, T., van der Molen, M. K., and Tamstorf, M. P.: Assessing the spatial variability in peak season $\mathrm{CO}_{2}$ exchange characteristics across 
the Arctic tundra using a light response curve parameterization, Biogeosciences, 11, 4897-4912, doi:10.5194/bg-11-4897-2014, 2014.

McGuire, A. D., Chapin, F. S., Walsh, J. E., and Wirth, C.: Integrated Regional Changes in Arctic Climate Feedbacks: Implications for the Global Climate System*, Annu. Rev. Environ. Resour., 31, 61-91, doi:10.1146/annurev.energy.31.020105.100253, 2006.

Merbold, L., Kutsch, W. L., Corradi, C., Kolle, O., Rebmann, C., Stoy, P. C., Zimov, S. A., and Schulze, E. D.: Artificial drainage and associated carbon fluxes $\left(\mathrm{CO}_{2} / \mathrm{CH}_{4}\right)$ in a tundra ecosystem, Glob. Change Biol., 15, 2599-2614, 2009.

Nordstroem, C., Soegaard, H., Christensen, T. R., Friborg, T., and Hansen, B. U.: Seasonal carbon dioxide balance and respiration of a high-arctic fen ecosystem in NE-Greenland, Theor. Appl. Climatol., 70, 149-166, doi:10.1007/s007040170012, 2001.

Oberbauer, S. F., Tweedie, C. E., Welker, J. M., Fahnestock, J. T., Henry, G. H. R., Webber, P. J., Hollister, R. D., Walker, M. D., Kuchy, A., Elmore, E., and Starr, G.: Tundra $\mathrm{CO}_{2}$ fluxes in response to experimental warming across latitudinal and moisture gradients, Ecol. Monogr., 77, 221-238, 2007.

Paul-Limoges, E., Christen, A., Coops, N. C., Black, T. A., and Trofymow, J. A.: Estimation of aerodynamic roughness of a harvested Douglas-fir forest using airborne LiDAR, Remote Sens. Environ., 136, 225-233, doi:10.1016/j.rse.2013.05.007, 2013.

Pérez-Priego, O., Serrano-Ortiz, P., Sánchez-Cañete, E. P., Domingo, F., and Kowalski, A. S.:Isolating the effect of subterranean ventilation on $\mathrm{CO}_{2}$ emissions from drylands to the atmosphere, Agr. Forest Meteorol., 180, 194-202, 2013.

Reichstein, M., Stoy, P. C., Desai, A. R., Lasslop, G., and Richardson, A. D.: Partitioning of net fluxes, in: Eddy Covariance: A Practical Guide to Measurement and Data Analysis, edited by: Aubinet, M., Vasala, T., and Papale, D., 263-289, Springer Atmospheric Sciences, 2012.

Robinson, S. D. and Pollard, W. H.: Massive ground ice within Eureka Sound bedrock, in Permafrost, Proc. 7th International Conf. on Permafrost, Yellowknife, Canada, Collection Nordicana, 2327 June 1998, 949-954, 1998.

Schuur, E. A. G., Bockheim, J., Canadell, J. G., Euskirchen, E., Field, C. B., Goryachkin, S. V., Hagemann, S., Kuhry, P., Lafleur, P. M., Lee, H., Mazhitova, G., Nelson, F. E., Rinke, A., Romanovsky, V. E., Shiklomanov, N., Tarnocai, C., Venetsky, S., Vogel, J. G., and Zimov, S. A.: Vulnerability of permafrost carbon to climate change: Implications for the global carbon cycle, Bioscience, 58, 701-714, 2008.

Schuur, E. A. G., McGuire, A. D., Grosse, G., Harden, J. W., Hayes, D. J., Hugelius, G., Koven, C. D., and Kuhry, P.: Climate change and the permafrost carbon feedback, Nature, 520, 171-179, doi:10.1038/nature14338, 2015.

Serrano-Ortiz, P., Roland, M., Sanchez-Moral, S., Janssens, I. A., Domingo, F., Godderis, Y., and Kowalski, A. S.: Hidden, abiotic $\mathrm{CO}_{2}$ flows and gaseous reservoirs in the terrestrial carbon cycle: Review and perspectives, Agr. Forest Meteorol., 150, 321-329, 2010 .
Starr, G. and Oberbauer, S. F.: Photosynthesis of arctic evergreens under snow: Implications for tundra ecosystem carbon balance, Ecology, 84, 1415-1420, doi:10.1890/02-3154, 2003.

Stoy, P., Williams, M., Evans, J., Prieto-Blanco, A., Disney, M., Hill, T., Ward, H., Wade, T., and Street, L.: Upscaling tundra $\mathrm{CO}_{2}$ exchange from chamber to eddy covariance tower, Arctic, Antarct. Alp. Res., 45, 275-284, doi:10.1657/1938-424645.2.275, 2013.

Tarnocai, C., Canadell, J. G., Schuur, E. A. G., Kuhry, P., Mazhitova, G., and Zimov, S.: Soil organic carbon pools in the northern circumpolar permafrost region, Global Biogeochem. Cy., 23, GB2023, doi:10.1029/2008GB003327, 2009.

Ukraintseva, N.: Vegetation response to landslide spreading and climate change in the west Siberian tundra, Proc. 9th International Conf. on Permafrost, Fairbanks, Alaska, 28 June-3 July 2008, 2, 1793-1798, 2008.

Vincent, W., Callaghan, T., Dahl-Jensen, D., Johansson, M., Kovacs, K., Michel, C., Prowse, T., Reist, J., and Sharp, M.: Ecological implications of changes in the Arctic cryosphere, Ambio, 40, 87-99, doi:10.1007/s13280-011-0218-5, 2011.

Vogel, J., Schuur, E. A. G., Trucco, C., and Lee, H.: Response of $\mathrm{CO}_{2}$ exchange in a tussock tundra ecosystem to permafrost thaw and thermokarst development, J. Geophys. Res.-Biogeosci., 114, G04018, doi:10.1029/2008JG000901, 2009.

Walter Anthony, K. M., Anthony, P., Grosse, G., and Chanton, J.: Geologic methane seeps along boundaries of Arctic permafrost thaw and melting glaciers, Nat. Geosci., 5, 419-426, doi:10.1038/ngeo1480, 2012.

Wang, T., Ciais, P., Piao, S. L., Ottlé, C., Brender, P., Maignan, F., Arain, A., Cescatti, A., Gianelle, D., Gough, C., Gu, L., Lafleur, P., Laurila, T., Marcolla, B., Margolis, H., Montagnani, L., Moors, E., Saigusa, N., Vesala, T., Wohlfahrt, G., Koven, C., Black, A., Dellwik, E., Don, A., Hollinger, D., Knohl, A., Monson, R., Munger, J., Suyker, A., Varlagin, A., and Verma, S.: Controls on winter ecosystem respiration in temperate and boreal ecosystems, Biogeosciences, 8, 2009-2025, doi:10.5194/bg8-2009-2011, 2011.

Welker, J. M., Fahnestock, J. T., and Jones, M. H.: Annual $\mathrm{CO}_{2}$ flux in dry and moist arctic tundra: Field responses to increases in summer temperatures and winter snow depth, Clim. Change, 44, 139-150, doi:10.1023/a:1005555012742, 2000.

Welker, J. M., Fahnestock, J. T., Henry, G. H. R., O’Dea, K. W., and Chimner, R. A.: $\mathrm{CO}_{2}$ exchange in three Canadian High Arctic ecosystems: Response to long-term experimental warming, Glob. Change Biol., 10, 1981-1995, 2004. 